Journal of Management and Bussines (JOMB)

Volume 1, Nomor 1, Juni 2019

p-ISSN : 2656-8918

e-ISSN: $2684-8317$

DOI : https://doi.org/10.31539/jomb.v1i1.658

\title{
ANALISIS FINANCIAL DISTRESS DENGAN METODE ZMIJEWSKI
}

\author{
Desi Permatasari $^{1}$ Acep Samsudin ${ }^{2}$ Kokom Komariah ${ }^{3}$ \\ Universitas Muhammadiyah Sukabumi ${ }^{1,2,3}$ \\ Email:desidp6@gmail.com ${ }^{1}$
}

\begin{abstract}
ABSTRAK
Penelitian ini bertujuan untuk mengetahui bagaimana metode zmijewski dapat digunakan dalam menganalisis financial distress pada PT. Jaya Konstruksi Manggala Pratama Tbk, PT. Indonesia Pondasi Raya Tbk, dan PT. Mitra Pemuda Tbk. Metode analisis data yang digunakan adalah dengan menggunakan metode zmijewski. Hasil penelitian, PT. Mitra Pemuda Tbk pada tahun 2015 memperoleh nilai X-Score sebesar 0,6868 sehingga perusahaan dikategorikan sehat atau non distress. Pada tahun 2016 PT. Mitra Pemuda memperoleh nilai X-Score sebesar -1,5004 dan dikategorikan non distress. Dan pada tahun 2017 PT. Mitra Pemuda Tbk memperoleh nilai X-Score sebesar -1,6922 sehingga berada dalam kategori sehat atau non distress. Simpulan, PT. Jaya Konstruksi Manggala Pratama Tbk, PT. Indonesia Pondasi Raya Tbk, dan PT. Mitra Pemuda Tbk berdasarkan metode zmijewski untuk menganalisis financial distress ketiga perusahaan berada dalam kondisi sehat atau non distress.
\end{abstract}

Kata Kunci : Financial Distress, Laporan Keuangan, Metode Zmijewski

\section{ABSTRACT}

This study aims to determine how the zmijewski method can be used in analyzing financial distress at PT. Jaya Konstruksi Manggala Pratama Tbk, PT. Indonesia Pondasi Raya Tbk, and PT. Mitra Pemuda Tbk. The data analysis method used is to use the zmijewski method. The results of the study, PT. Mitra Pemuda Tbk in 2015 obtained an X-Score of -0.6868 so that the company was categorized as healthy or non-distress. In 2016 PT. Mitra Pemuda obtains an X-Score value of -1,5004 and is categorized as non-distress. And in 2017 PT. Mitra Pemuda Tbk obtained the X-Score value of -1.6922 so that it was in the category of healthy or non-distress. Conclusion, PT. Jaya Konstruksi Manggala Pratama Tbk, PT. Indonesia Pondasi Raya Tbk, and PT. Mitra Pemuda Tbk based on the zmijewski method to analyze the company's third financial distress is in a healthy or non-distress condition.

Keywords: Financial Distress, Financial Report, Zmijewski Method

\section{PENDAHULUAN}

Pada zaman sekarang ini di kota-kota besar seperti Jakarta banyak gedung perusahaan, kampus, pusat perbelanjaan juga infrastruktur seperti jalan tol di bangun untuk memfasilitasi masyarakat. Seperti gedung perusahaan digunakan untuk tempat 
bekerja para karyawan, kampus untuk mahasiswa melaksanakan kuliah, pusat perbelanjaan untuk membeli kebutuhan sehari-hari.

Untuk membangun gedung perusahaan, kampus, juga pusat perbelanjaan dibutuhkan perusahaan yang bergerak dalam bidang konstruksi untuk membangun bangunan pada kota atau kabupaten tertentu. Namun, seiring berjalannya waktu banyak perusahaan konstruksi didirikan sehingga dapat menyebabkan suatu perusahaan dalam bidang konstruksi mengalami penurunan laba.

Perusahaan dalam bidang konstruksi merupakan suatu organisasi yang didirikan oleh perorangan maupun kelompok dengan menghasilkan jasa yang kemudian dapat menghasilkan keuntungan. Dalam menjaga kestabilan pendapatan, perusahaan harus menjaga jasa yang dihasilkan dengan cara menjaga kestabilan harga agar tidak mengalami kerugian yang dapat mengarah ke financial distress. .

Financial distress dapat diketahui dengan analisis data dalam laporan keuangan. Laporan keuangan biasanya dibuat pada setiap akhir tahun untuk melihat berapa aset, hutang, maupun laba yang didapat dari usaha yang dilakukan selama satu tahun terakhir. Laporan keuangan historis perusahaan penting untuk dianalisis, sebab berdasarkan informasi yang tersaji di dalamnya dapat diperoleh gambaran yang dapat digunakan sebagai alat untuk mengevaluasi kinerja keuangan, sehingga diharapkan dari evaluasi tersebut, kinerja keuangan perusahan akan lebih baik dari waktu ke waktu.

Kinerja keuangan perusahaan dapat berguna untuk mengukur tingkat keberhasilannya dalam menghasilkan laba sehingga perusahaan dapat melihat potensi juga pertumbuhan perusahaan. Hal ini dapat berguna bagi investor yang akan berinvestasi pada perusahaan karena dapat mengetahui kinerja keuangan perusahaan sehingga dapat melakukan pertimbangan terlebih dahulu sebelum melakukan investasi.

Investasi pada suatu perusahaan biasanya akan mengalami resiko tidak kepastian di waktu yang akan datang. Resiko yang dapat terjadi diantaranya tidak ada pengembalian investasi seperti yang diaharapkan. Hal ini terjadi karena perusahaan tidak dapat melakukan jadwal pembayaran. "Setiap perusahaan harus mewaspadai adanya potensi kebangkrutan, oleh karena itu perusahaan harus melakukan analisis yang menyangkut kebangkrutan perusahaan (Mastuti, 2013).

PT. Jaya Konstruksi Manggala Pratama Tbk, PT. Indonesia Pondasi Raya Tbk, dan PT. Mitra Pemuda Tbk merupakan perusahaan yang bergerak dalam bidang 
konstruksi yang terdaftar di Bursa Efek Indonesia yang mengalami masalah yaitu adanya penurunan laba bersih pada periode 2015-2017. Padahal laba bersih merupakan keuntungan bersih yang diharapkan perusahaan mengalami kenaikan setiap tahunnya karena laba bersih berguna untuk mengukur kinerja keuangan perusahaan untuk mengetahui perusahaan dalam keadaan baik atau tidak. Jika laba bersih yang dihasilkan mengalami penurunan, perusahaan sedang mengalami ciri-ciri keadaan financial distress atau kesulitan keuangan.

Untuk mengetahui apakah perusahaan mengalami financial distress (kesulitan keuangan) yang mengarah kedalam kebangkrutan dapat menggunakan berbagai metode analisis. Metode analisis yang dapat digunakan adalah metode Zmijewski. Analisis financial distress ini cara menghitungnya cukup mudah dan juga cukup akurat. Analisis financial distress tersebut dapat digunakan perusahaan untuk penilaian dan juga pertimbangan terhadap kondisi perusahaan pada masa yang akan datang.

Rahayu, Suwendra dan Yulianthini (2016) melakukan penelitian yang berjudul analisis financial distress dengan menggunakan metode Altman Z-Score, Springate, dan Zmijewski pada perusahaan Telekomunikasi. Berdasarkan hasil perhitungan dari ketiga metode yaitu Altman, Springate, dan Zmijewski diperoleh dua dari tiga metode menunjukkan perusahaan dikategorikan dalam kondisi financial distress, maka dapat diartikan bahwa perusahaan Telekomunikasi selama periode 2012-2014 sebagian besar berada pada kondisi mengalami kesulitan keuangan (financial distress).

Kemudian penelitian yang dilakukan Umi Ambarwati, Sudarwati, dan Rochmi Widayan (2016) dalam penelitiannya yang berjudul Financial distress dengan metode springate, zmijewski, fulmer dan altman z-score pada PT Tunas Baru Lampung Tbk di BEI. Hasil penelitian menunjukkan bahwa : (1) Menurut Altman Z-Score tahun 2013 dan 2015 mengalami bangkrut sedangkan tahun 2014 berada dalam grey area. (2) Menurut Springate tahun 2013-2015 mengalami bangkrut karena berada dibawah kriteria nilai kesehatan perusahaan. (3) Menurut Zmijewski tahun 2013-2015 mengalami sehat dengan hasil yang negative. (4) Menurut Fulmer tahun 2013 dan 2014 mengalami kondisi yang sehat tetapi tahun 2015 mengalami kondisi yang bangkrut. 


\section{KAJIAN TEORI}

\section{Lapora Keuangan}

Menurut Fahmi (2013) : Laporan keuangan merupakan suatu informasi yang menggambarkan kondisi suatu perusahaan, dimana selanjutnya itu akan menjadi suatu informasi yang menggambarkan tentang kinerja suatu perusahaan..

\section{Financial Distress}

Menurut Fahmi (2013): mendefinisikan bahwa financial distress adalah tahap penurunan kondisi keuangan yang dialami oleh suatu perusahaan yang terjadi sebelum mengalami kebangkrutan atau likuidasi, yang terjadi sebelum terjadinya kebangkrutan adapun likuidasi.

\section{Metode Zmijewski}

Zmijewski melakukan studi dengan menelaah ulang studi bidang kebangkrutan hasil riset sebelumnya selama dua puluh tahun. Beberapa rasio keuangan dipilih dari rasio-rasio keuangan penelitian terdahulu dan diambil sampel sebanyak 75 perusahaan yang bangkrut, serta 3573 perusahaan yang sehat selama tahun 1972 sampang dengan 1978, indikator F-test terhadap rasio-rasio kelompok, Rate of Return, liquidity, leverage, turnover, fixed payment coverage, trends, firm size, dan stock return volatility, menunjukkan adanya perbedaan yang signifikan antara perusahaan yang sehat dengan yang tidak sehat. Berikut ini rumus yang dikemukakan oleh Zmijewski:

$$
\mathrm{X}-\text { Score }=-4,3-4,5 \mathrm{X} 1+5,7 \mathrm{X} 2-0,004 \mathrm{X} 3
$$

Sumber : Nur Fajrina Dewi, 2015

Dimana :

X1 = Earning After Tax/Total Assets (Return On Assets)

$$
\begin{array}{cc}
\text { Earning After Tax/Total } & \text { Laba Bersih } \\
\cline { 2 - 2 } \text { Assets }= & \text { Total Aktiva }
\end{array}
$$

ROA merupakan rasio yang membandingkan laba setelah pajak dengan total asetnya. Rasio ini menunjukkan seberapa baik perusahaan menggunakan aset yang diinvestasikan untuk dibagikan dengan laba yang dihasilkan. Laba setelah pajak 
diperoleh dari laporan laba rugi, dan total aset diperoleh dari neraca. Semakin besar ROA, semakin efisien penggunaan aktiva perusahaan, dan sebaliknya, semakin kecil ROA, maka penggunaan aktiva perusahaan semakin tidak efisien (Sudana, 2011). $\mathrm{X} 2=$ Total Debt/Total Assets (Debt Ratio/Leverage $)$

\begin{tabular}{cc}
\hline Total Debt/ \\
Total Assets $=$
\end{tabular}

Rasio ini merupakan rasio yang membandingkan antara total hutang dengan total aset. Rasio ini digunakan untuk mengukur likuiditas perusahaan secara total. Semua data diperoleh dari neraca perusahaan. Semakin besar rasio, maka semakin besar pula penggunaan utang dalam membiayai investasi pada aktiva, yang berarti risiko keuangan perusahaan juga semakin meningkat.

$\mathrm{X} 3=$ Current Assets/Current Liabilities (Current Ratio atau Likuiditas)

\begin{tabular}{cl} 
Current Assets/Current & \multicolumn{1}{c}{ Aktiva Lancar } \\
Liabilities $=$ & Kewajiban Lancar \\
\hline
\end{tabular}

Rasio ini diukur dengan membandingkan antara aktiva lancar dengan hutang lancar. Rasio ini untuk mengukur likuiditas perusahaan, namun difokuskan dalam jangka pendek. Semua data diperoleh dari neraca perusahaan.

Kriteria :

Cut-off yang digunakan dalam model ini adalah 0, dimana jika hasil X-Score bernilai positif, maka perusahaan tersebut dikatakan tidak sehat. Sedangkan jika hasil X-Score bernilai negatif, maka perusahaan dikatakan sehat. (Purnajayadan Merkusiwati, 2014).

\section{Kelebihan Dan Kekurangan Metode Zmijewski}

Kelebihan dan kekurangan metode Zmijewski menurut BAPEPAM dalam Nurcahyanti (2015) kelebihan meliputi; 1) menggabungkan berbagai rasio keuangan secara bersama-sama; 2) menyediakan koefisien yang sesuai untuk mengkombinasikan variabel-variabel independen; 3) mudah dalam penerapannya. Kekurangan 1) nilai bisa 
direkayasa atau dibiaskan melalui prinsip akuntansi yang salah atau rekayasa keuangan lainnya; 2) hanya menggunakan tiga rasio saja; 3) metode Zmijewski tidak ketat dalam menilai tingkat kebangkrutan.

\section{METODE PENELITIAN}

Metode penelitian yang digunakan dalam penelitian ini merupakan metode deskriptif kuantitatif, yaitu dengan cara mengumpulkan, mengklasifikasikan, menganalisis, dan menginterprestasikan data-data yang diperoleh dari perusahaan sehingga dapat memberikan gambaran dengan keadaan yang sebenarnya (Arikunto, 2010).

Menurut Sugiyono (2013) metode deskriptif adalah metode yang mampu menjelaskan rumusan masalah yang berkenaan dengan pertanyaan terhadap keberadaan variabel mandiri, baik hanya satu variabel atau lebih (variabel mandiri adalah variabel yang berdiri sendiri, bukan variabel independen, karena variabel independen selalu dipasangkan dengan variabel dependen).

Data yang digunakan dalam penelitian ini merupakan data sekunder yaitu berupa dokumentasi dan studi kepustakaan. Dan data didapatkan secara tidak langsung dari perusahaan bersangkutan yang menjadi objek penelitian, melainkan dari sumber lain yaitu internet melalui situs resmi Bursa Efek Indonesia dengan alamat website www.idx.co.id. Metode analisis data yang digunakan dalam penelitian ini adalah Metode Zmijewski.

$$
\mathrm{X} \text {-Score }=-4,3-4,5 \mathrm{X} 1+5,7 \mathrm{X} 2-0,004 \mathrm{X} 3
$$

Dimana :

$\mathrm{X} 1=$ EAT/Total Assets (Return On Assets)

$\mathrm{X} 2$ = Total Debt/Total Assets (Debt Ratio/Leverage)

X3 = Current Assets/Current Liabilities (Current Ratio atau Likuiditas)

Cut-off yang digunakan dalam model ini adalah 0, dimana jika hasil X-Score bernilai positif, maka perusahaan tersebut dikatakan tidak sehat. Sedangkan jika hasil X-Score bernilai negatif, maka perusahaan dikatakan sehat. Tingkat akurasi metode Zmijewski ini sebesar 94,9\% . (Purnajaya dan Merkusiwati, 2014) 


\section{HASIL PENELITIAN}

Berdasarkan data yang dikeularkan oleh PT. Jaya Konstruksi Manggala Pratama Tbk PT. Indonesia Pondasi Raya Tbk dan PT. Mitra Pemuda Tbk melalui Bursa Efek Indonesia berupa laporan tahunan perusahaan selama tiga tahun terhitung tahun 2015-2017. Laporan tahunan tersebut mencakup laporan Dewan Komisaris, laporan Presiden Direktur, dan laporan keuangan perusahaan yang diperuntukan bagi pemegang saham dan pihak-pihak yang memiliki kepentingan dengan laporan tersebut.

Metode zmijewski merupakan metode yang dikembangkan oleh Zmijewski pada tahun 1985. Metode ini digunakan untuk mengetahui apakah perusahaan mengalami financial distress atau tidak. Dalam metode ini terdapat tiga indikator rasio keuangan yang dikombinasikan dalam sebuah rumus, yaitu earning after tax to total assets (Return On Assets), total debt to total assets (Debt Ratio atau Leverage), dan current assets to current liabilities (Current Ratio atau Likuiditas).

\section{Earning After Tax To Total Assets (X1)}

ROA merupakan rasio yang membandingkan laba bersih dengan total aset. Rasio ini digunakan untuk mengukur seberapa besar perusahaan dapat memanfaatkan aktivanya dalam memperoleh laba. Semakin besar ROA, semakin efisien penggunaan aktiva perusahaan, dan sebaliknya, semakin kecil ROA, maka penggunaan aktiva perusahaan semakin tidak efisien (Sudana, 2011).

Tabel 1

Hasil Perhitungan X1

\begin{tabular}{lccc}
\hline \multicolumn{1}{c}{ Nama Perusahaan } & Tahun & $\mathbf{2 0 1 7}$ \\
\hline PT. Jaya Konstruksi Manggala Pratama Tbk & $6,21 \%$ & $8,28 \%$ & $7,38 \%$ \\
PT. Indonesia Pondasi Raya Tbk & $16,49 \%$ & $7,78 \%$ & $6,19 \%$ \\
PT. Mitra Pemuda Tbk & $21,95 \%$ & $3,82 \%$ & $3,82 \%$ \\
\hline
\end{tabular}

Sumber : Diolah oleh peneliti, 2019

Berdasarkan hasil perhitungan X1 pada PT. Jaya Konstruksi Manggala Pratama Tbk periode 2015-2017, perusahaan belum mampu menggunakan total aktiva secara efisien dalam menghasilkan laba karena hasil dari perhitungan laba bersih dibagi dengan total aktiva hasilnya menunjukan adanya fluktuasi. Dan hasil dari perhitungan X1 pada PT. Indonesia Pondasi Raya Tbk periode 2015-2017 dan PT. Mitra Pemuda 
Tbk periode 2015-2017, kedua perusahaan belum mampu menggunakan total aktiva secara efisien dalam menghasilkan laba karena hasil dari perhitungan laba bersih dibagi dengan total aktiva menunujukan adanya penurunan. Hal ini disebabkan karena laba bersih mengalami fluktuasi dan total aktiva mengalami penurunan.

\section{Total Debt To Total Assets (X2)}

Debt ratio atau leverage merupakan rasio yang membandingkan antara total hutang dengan total aset. Rasio ini digunakan untuk mengukur likuiditas perusahaan secara keseluruhan. Semakin besar rasio ini, maka semakin besar pula penggunaan utang dalam membiayai investasi pada aktiva, yang berarti risiko keuangan perusahaan jugasemakinmeningkat.

Tabel 2

Hasil perhitungan X2

\begin{tabular}{lccc}
\multicolumn{1}{c}{ Nama Perusahaan } & $\mathbf{2 0 1 5}$ & $\mathbf{2 0 1 6}$ & $\mathbf{2 0 1 7}$ \\
\hline PT. Jaya Konstruksi Manggala Pratama Tbk & $48,98 \%$ & $45,08 \%$ & $42,82 \%$ \\
PT. Indonesia Pondasi Raya Tbk & $28,15 \%$ & $28,48 \%$ & $34,34 \%$ \\
PT. Mitra Pemuda Tbk & $80,82 \%$ & $52,25 \%$ & $48,89 \%$ \\
\hline
\end{tabular}

Sumber : Diolah oleh peneliti, 2019

Hasil dari perhitungan X2 pada PT. Jaya Konstruksi Manggala Pratama Tbk periode 2015-2107, perusahaan tidak akan mengalami resiko keuangan yang buruk karena pada tahun 2015-2017 aktiva yang dibiayai oleh hutang terus menurun.. Lalu hasil dari perhitungan X2 pada PT. Indonesia Pondasi Raya Tbk periode 2015-2017, perusahaan mungkin akan mengalami resiko keuangan yang buruk karena pada tahun 2015-2017 aktiva yang dibiayai oleh hutang terus meningkat.. Dan hasil dari perhitungan X2 pada PT. Mitra Pemuda Tbk periode 2015-2017 perusahaan tidak akan mengalami resiko keuangan yang buruk karena pada tahun 2015-2017 aktiva yang dibiayai oleh hutang terus menurun.

\section{Current Assets To Current Liabilities (X3)}

Current ratio atau likuiditas merupakan rasio yang membandingkan aktiva lancar dengan kewajiban lancar. Rasio ini digunakan untuk mengukur tingkat likuiditas perusahaan. Likuiditas perusahaan sudah dapat dianggap baik jika nilai rasio lancarnya 
sama dengan 2. Semakin tinggi hasil perhitungan rasio ini maka semakin terjamin hutang-hutang perusahaan kepada kreditur, karena bagi kreditur semakin tinggi nilai rasio ini semakin bagus

Tabel 3

Hasil perhitungan X3

\begin{tabular}{lcccc}
\hline \multicolumn{1}{c}{ Nama Perusahaan } & $\mathbf{2 0 1 5}$ & $\mathbf{2 0 1 6}$ & $\mathbf{2 0 1 7}$ & Rata-rata \\
& & & & \\
\hline $\begin{array}{l}\text { PT. Jaya Konstruksi Manggala Pratama } \\
\text { Tbk }\end{array}$ & $164,87 \%$ & $169,29 \%$ & $170,37 \%$ & $168,17 \%$ \\
PT. Indonesia Pondasi Raya Tbk & $313,95 \%$ & $261,80 \%$ & $270,39 \%$ & $282,04 \%$ \\
PT. Mitra Pemuda Tbk & $143,70 \%$ & $169.11 \%$ & $176,67 \%$ & $163,16 \%$
\end{tabular}

Sumber : Diolah oleh peneliti, 2019

Hasil dari perhitungan X3 pada PT. Jaya Konstruksi Manggala Pratama Tbk periode 2015-2017 mempunyai Current ratio dibawah 200\% atau 2,0 sehingga dapat dikatakan kategori likuiditas yang tidak baik. Lalu hasil dari perhitungan X3 pada PT. Indonesia Pondasi Raya Tbk periode 2015-2017 Tbk mempunyai Current ratio diatas $200 \%$ atau 2,0 sehingga dapat dikatakan kategori likuiditas yang baik. Dan hasil dari perhitungan X3 pada PT. Mitra Pemuda Tbk periode 2015-2017 mempunyai Current ratio dibawah $200 \%$ atau 2,0 sehingga dapat dikatakan kategori likuiditas yang tidak baik

\section{Hasil Perhitungan Financial Distress Dengan Metode Zmijewski}

Tabel 4

Hasil Perhitungan Financial Distress Dengan Metode Zmijewski

\begin{tabular}{ccccccc}
\hline Tahun & & $\mathbf{4 , 5}(\mathbf{X 1})$ & $\mathbf{5 , 7}(\mathbf{X 2})$ & $\mathbf{0 , 0 0 4}(\mathbf{X 3})$ & X-Score & Hasil Prediksi \\
\hline 2015 & $-4,3$ & 0,0621 & 0,4898 & 1,6487 & $-1,7942$ & Non Distress \\
2016 & $-4,3$ & 0,0828 & 0,4508 & 1,6929 & $-2,1098$ & Non Distress \\
2017 & $-4,3$ & 0,0738 & 0,4282 & 1,7037 & $-2,1982$ & Non Distress \\
\hline
\end{tabular}

Sumber : Diolah oleh peneliti, 2019

PT. Jaya Konstruksi Manggala Pratama Tbk pada tahun 2015 memperoleh nilai X-Score sebesar -1,7942 sehingga perusahaan dikategorikan non distress karena pada metode zmijewski jika hasil X-Score negatif maka perusaaan dikategorikan non distress. Pada tahun 2016 PT. Jaya Konstruksi Manggala Pratama Tbk memperoleh 
nilai X-Score sebesar -2,1908 sehingga perusahaan dikategorikan non distress. Terjadi penurunan nilai X-Score pada tahun 2016 dan ini berdampak baik bagi perusahaan. Penurunan terjadi karena naiknya nilai X1 yang disebabkan oleh kenaikan laba usaha dan penurunan pada nilai X2 terjadi karena kenaikan total aset. Dan pada tahun 2017 PT. Jaya Konstruksi Manggala Pratama Tbk memperoleh nilai X-Score -2,1982. Pada tahun 2017 nilai X-Score mengalami penurunan dari tahun sebelumnya, hal ini berdampak baik bagi perusahaan.

Penurunan terjadi karena X1 dan X2 mengalami penurunan dan X3 mengalami peningkatan. Penurunan pada X1 dan X2 disebabkan oleh naiknya total aset dan peningkatan pada X3 disebabkan oleh menurunnya kewajiban lancar pada perusahaan. Jadi PT. Jaya Konstruksi Manggala Pratama Tbk periode 2015-2017 perusahaan berada dalam keadaan sehat atau non distress, namun perusahaan harus tetap menjaga kestabilan keuangan perusaaan seperti meningkatnya penjualan sehingga laba bersih yang diperoleh akan mengalami peningkatan dan perusahaan harus mampu memenuhi kewajibannya.

Tabel 5

Hasil Perhitungan Financial Distress Dengan Metode Zmijewski

\begin{tabular}{ccccccc}
\hline Tahun & & $\mathbf{4 , 5}(\mathbf{X 1})$ & $\mathbf{5 , 7}(\mathbf{X 2})$ & $\mathbf{0 , 0 0 4}(\mathbf{X 3})$ & X-Score & Hasil Prediksi \\
\hline 2015 & $-4,3$ & 0,1649 & 0,2815 & 3,1395 & $-3,4501$ & Non Distress \\
2016 & $-4,3$ & 0,0778 & 0,2848 & 2,6180 & $-3,0372$ & Non Distress \\
2017 & $-4,3$ & 0,0619 & 0,3434 & 2,7039 & $-2,6319$ & Non Distress \\
\hline
\end{tabular}

Sumber : Diolah oleh peneliti, 2019

PT. Indonesia Pondasi Raya Tbk pada tahun 2015 memperoleh nilai X-Score sebesar -3,4501 sehingga perusahaan dikategorikan non distress. Pada tahun 2016 PT. Indonesia Pondasi Raya Tbk memperoleh nilai X-Score sebesar -3,0372. Terjadi peningkatan nilai X-Score pada tahun 2016 dibandingkan tahun 2015 disebabkan oleh penurunan nilai $\mathrm{X} 1$ dan $\mathrm{X} 3$ dan peningkatan pada nilai $\mathrm{X} 2$. Penurunan pada $\mathrm{X} 1$ terjadi karena naiknya total aset, peningkatan pada X2 terjadi karena naiknya total kewajiban, dan penurunan pada X3 terjadi karena naiknya kewajiban lancar. Dan pada tahun 2017 PT. Indonesia Pondasi Raya Tbk memperoleh nilai X-Score sebesar -2,6319. Pada tahun 2017 terjadi peningkatan nilai X-Score pada PT. Indonesia Pondasi Raya Tbk, hal ini disebabkan oleh penurunan nilai $\mathrm{X} 1$ dan peningkatan pada nilai X2 dan X3. Penurunan pada X1 terjadi karena naiknya total aset, peningkatan pada X2 terjadi 
karena naiknya total kewajiban dan peningkatan pada X3 terjadi karena naiknya nilai aset lancar.

Jadi PT. Indonesia Pondasi Raya Tbk periode 2015-2017 dikategorikan sehat atau non distress, akan tetapi terjadi peningkatan nilai X-Score setiap tahunnya dan ini berdampak buruk bagi perusahaan, sehingga perusahaan harus meningkatkan penjualan agar laba bersih yang diperoleh meingkat setiap tahunnya dan kewajiban lancar harus mengalami penurunan setiap tahunnya dengan mengurangi pinjaman karena jika total kewajiban terus meningkat dan perusahaan tidak mampu membayarnya maka perusahaan dapat mengarah kedalam financial distress. Dan jika perusahaan mengalami peningkatan nilai X-Score pada tahun selanjutnya dan nilai yang diperoleh adalah positif maka perusahaan dapat dikategorikan tidak sehat atau distress

Tabel 6

Hasil Perhitungan Financial Distress Dengan Metode Zmijewski

\begin{tabular}{ccccccc}
\hline Tahun & & $\mathbf{4 , 5}(\mathbf{X 1})$ & $\mathbf{5 , 7}(\mathbf{X 2})$ & $\mathbf{0 , 0 0 4}(\mathbf{X 3})$ & $\mathbf{X}$-Score & Hasil Prediksi \\
\hline 2015 & $-4,3$ & 0,2195 & 0,8082 & 1,4370 & $-0,6868$ & Non Distress \\
2016 & $-4,3$ & 0,0382 & 0,5225 & 1,6911 & $-1,5004$ & Non Distress \\
2017 & $-4,3$ & 0,0382 & 0,4889 & 1,7667 & $-1,6922$ & Non Distress \\
\hline
\end{tabular}

Sumber : Diolah oleh peneliti, 2019

PT. Mitra Pemuda Tbk pada tahun 2015 memperoleh nilai X-Score sebesar 0,6868 sehingga perusahaan dikategorikan sehat atau non distress. Pada tahun 2016 PT. Mitra Pemuda memperoleh nilai X-Score sebesar -1,5004. Terjadi penurunan nilai XScore pada tahun 2016 dibandingkan tahun sebelumnya yang disebabkan oleh penurunan nilai $\mathrm{X} 1$ dan $\mathrm{X} 2$ dan peningkatan nilai X3. Penurunan pada nilai $\mathrm{X} 1$ dan $\mathrm{X} 2$ disebabkan oleh naiknya total aset dan peningkatan pada X3 disebabkan oleh turunnya kewajiban lancar. Dan pada tahun 2017 PT. Mitra Pemuda Tbk memperoleh nilai XScore sebesar -1,6992. Terjadi penurunan nilai X-Score pada PT. Mitra Pemuda Tbk dibandingkan tahun sebelumnya yang disebabkan oleh penurunan nilai X2 dan peningkatan pada nilai X3.

Penurunan pada X2 terjadi karena naiknya total aset dan peningkatan pada X3 disebabkan oleh naiknya aset lancar. Jadi PT. Mitra Pemuda Tbk periode 2015-2017 berada dalam kategori sehat atau non distress. Akan tetapi jika perusahaan terus mengalami peningkatan total kewajiban dan kewajiban lancar maka perusahaan dapat 
mengarah kedalam kondisi financial distress. Sehingga perusahaan harus terus meningkatkan penjualan pada setiap tahunnya untuk memperoleh laba bersih yang besar dan dapat memenuhi kewajibannya agar hasil laba bersih yang diperoleh tidak menurun.

\section{PEMBAHASAN}

\section{Analisis Financial Distress Dengan Metode Zmijewski}

Berdasarkan hasil penelitian yang telah dijelaskan diatas PT. Jaya Konstruksi Manggala Pratama Tbk pada tahun 2015 memperoleh nilai X-Score sebesar -1,7942 sehingga perusahaan dikategorikan non distress. Pada tahun 2016 PT. Jaya Konstruksi Manggala Pratama Tbk memperoleh nilai X-Score sebesar -2,1908 sehingga perusahaan dikategorikan non distress. . Dan pada tahun 2017 PT. Jaya Konstruksi Manggala Pratama Tbk memperoleh nilai X-Score -2,1982. Pada tahun 2017 nilai X-Score mengalami penurunan dari tahun sebelumnya, dan perusahaan dikategorikan non distress. Seperti yang telah ditentukan oleh Zmijewski dimana jika hasil X-Score bernilai positif, maka perusahaan tersebut dikatakan tidak sehat. Sedangkan jika hasil X-Score bernilai negatif, maka perusahaan dikatakan sehat. (Purnajaya dan Merkusiwati, 2014).

\section{Analisis Financial Distress Dengan Metode Zmijewski}

Berdasarkan hasil penelitian yang telah dijelaskan diatas PT.Indonesia Pondasi Raya Tbk pada tahun 2015 memperoleh nilai X-Score sebesar -3,4501 sehingga perusahaan dikategorikan non distress. Pada tahun 2016 PT. Indonesia Pondasi Raya Tbk memperoleh nilai X-Score sebesar -3,0372 dan dikategorikan non distress. Pada tahun 2017 terjadi peningkatan nilai X-Score pada PT. Indonesia Pondasi Raya Tbk dan memperoleh X-Score sebesar -2,6319 dan dikategorikan sehat atau non distress. Seperti yang telah ditentukan oleh Zmijewski dimana jika hasil X-Score bernilai positif, maka perusahaan tersebut dikatakan tidak sehat. Sedangkan jika hasil X-Score bernilai negatif, maka perusahaan dikatakan sehat. (Purnajaya dan Merkusiwati, 2014).

\section{Analisis Financial Distress Dengan Metode Zmijewski}

Berdasarkan hasil penelitian yang telah dijelaskan diatas PT. Mitra Pemuda Tbk pada tahun 2015 memperoleh nilai X-Score sebesar -0,6868 sehingga perusahaan 
dikategorikan sehat atau non distress. Pada tahun 2016 PT. Mitra Pemuda memperoleh nilai X-Score sebesar -1,5004 dan dikategorikan non distress. Dan pada tahun 2017 PT. Mitra Pemuda Tbk memperoleh nilai X-Score sebesar -1,6922 sehingga berada dalam kategori sehat atau non distress. Seperti yang telah ditentukan oleh Zmijewski dimana jika hasil X-Score bernilai positif, maka perusahaan tersebut dikatakan tidak sehat. Sedangkan jika hasil X-Score bernilai negatif, maka perusahaan dikatakan sehat. (Purnajayadan Merkusiwati, 2014).

\section{SIMPULAN}

Berdasarkan hasil dan pembahasan yang telah dijelaskan diatas mengenai Analisis Financial Distress Pada PT. Jaya Konstruksi Manggala Pratama Tbk PT. Indonesia Pondasi Raya Tbk dan PT. Mitra Pemuda Tbk periode 2015-2017 dengan menggunakan metode zmijewski ketiga perusahaan tersebut masuk dalam kategori sehat atau non distress. Perusahaan dikategorikan non distress, karena hasil X-Score yang diperoleh adalah negatif. Akan tetapi perusahaan harus bisa memenuhi kewajibannya dan mengurangi kewajiban setiap tahunnya agar tidak mengarah kedalam financial distress. Perusahaan harus terus meningkatkan penjualan setiap tahunnya agar laba bersih yang diperoleh lebih besar dari kewajiban perusahaan.

\section{DAFTAR PUSTAKA}

Arikunto, Suharsimi. (2010). Prosedur Penelitian, Edisi Revisi. Yogyakarta: Rineka Cipta.

Fahmi Irham. (2013). Analisis Laporan Keuangan. Bandung : Afabeta.

Mastuti, (2013). Altman Z-Score Sebagai Salah Satu Metode Dalam Menganalisis Estimasi Kebangkrutan Perusahaan (Studi Pada Perusahaan Plastik dan Kemasan yang Terdaftar (Listing) di Bursa Efek Indonesia Periode Tahun 2010-2012. Fakultas Ilmu Administrasi, Universitas Brawijaya: Malang

Nurcahyani. (2015). Studi Komparatif Model Z-Score Altman, Springate, dan Zmijewski Dalam Mendedikasikan Kebangkrutan Perusahaan Yang Tedaftar Di BEI. Atikel Ilmiah. Universitas Negeri Padang.

Purnajaya, K. D. M., \& Merkusiwati, N. K. L. A. (2014). Analisis Komparasi Potensi Kebangkrutan dengan Metode Z-Score Altman, Springate, dan Zmijewski pada Industri Kosmetik yang Terdaftar di Bursa Efek Indonesia. E-Jurnal Akuntansi, 7(1), Hal. 48-63

Rahayu, F., Suwendra, I.W., dan Yulianthini, N.N (2016). Analisis Financial Distress Dengan Metode Altman Z-Score, Springate, dan Zmijewski Pada Perusahaan Telekomunikasi. E-Journal Bisma Universitas Pendidikan Ganesha Jurusan Manajemen, 4 (3): 89-99 
Sudana, I Made. (2011). Manajemen Keuangan Perusahaan Teori dan Praktik. Jakarta: Erlangga

Sugiyono. (2013). Metode Penelitian. Bandung: Alphabeta

Umi Ambarwati, Sudarwati, Rochmi Widayanti. (2017). Analisis Financial Distress Pada Pt Tunas Baru Lampung Tbk Di Bursa Efek Indonesia. Jurnal Organisasi dan Manajemen, 13(2), 129-141 